\title{
HOLLOW VOLCANIC TUMULUS CAVES OF KILAUEA CALDERA, HAWAII COUNTY, HAWAII
}

\author{
William R. Halliday *
}

\begin{abstract}
In addition to lava tube caves with commonly noted features, sizable subcrustal spaces of several types exist on the floor of Kilauea Caldera. Most of these are formed by drainage of partially stabilized volcanic structures enlarged or formed by injection of very fluid lava beneath a plastic crust. Most conspicuous are hollow tumuli, possibly first described by Walker in 1991. Walker mapped and described the outer chamber of Tumulus E-1 Cave. Further exploration has revealed that it has a hyperthermic inner room beneath an adjoining tumulus with no connection evident on the surface. Two lengthy, sinuous hollow tumuli also are present in this part of the caldera. These findings support Walker's conclusions that hollow tumuli provide valuable insights into tumulus-forming mechanisms, and provide information about the processes of emplacement of paboehoe sheet flows.
\end{abstract}

Keywords: geomorphology, lava caves, speleogenesis, Hawaii

\section{INTRODUCTION}

In addition to lava tube caves with commonly observed features, sizable caves of several other types exist on the floor of Kilauea Caldera. Most of these were formed by drainage of partially stabilized subcrustal structures enlarged or formed by injection of very fluid lava beneath a plastic crust. Most conspicuous of these are hollow tumuli, of which at least two distinct types are present. In this paper I follow the usage of Walker (1991), thus differentiating tumuli from lava rises. Caves of the latter show significant differences from those discussed here, and will be the subject of a later paper.

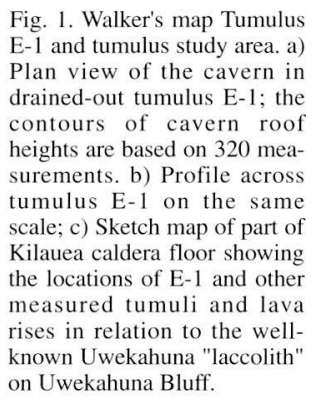

* Hawaii Speleological Survey 6530 Cornwall Court - Nashville, TN USA 37205.

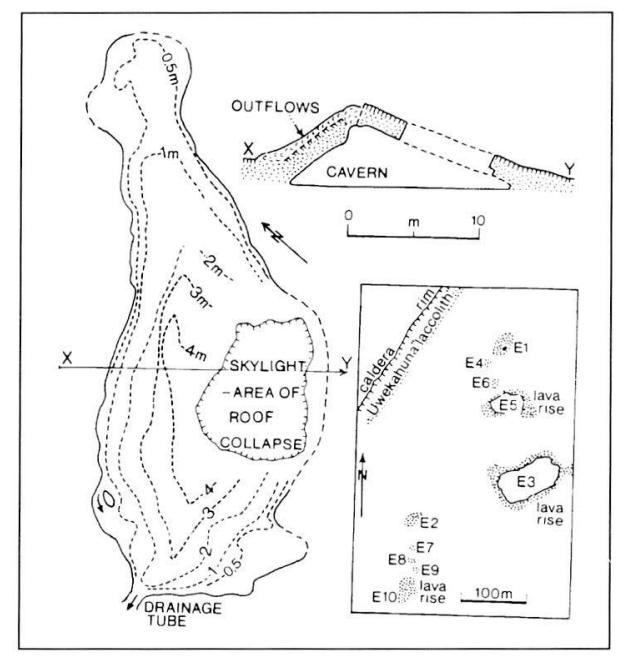


Fig. 2. Tumulus E-1 from caldera floor. Photo by the author.
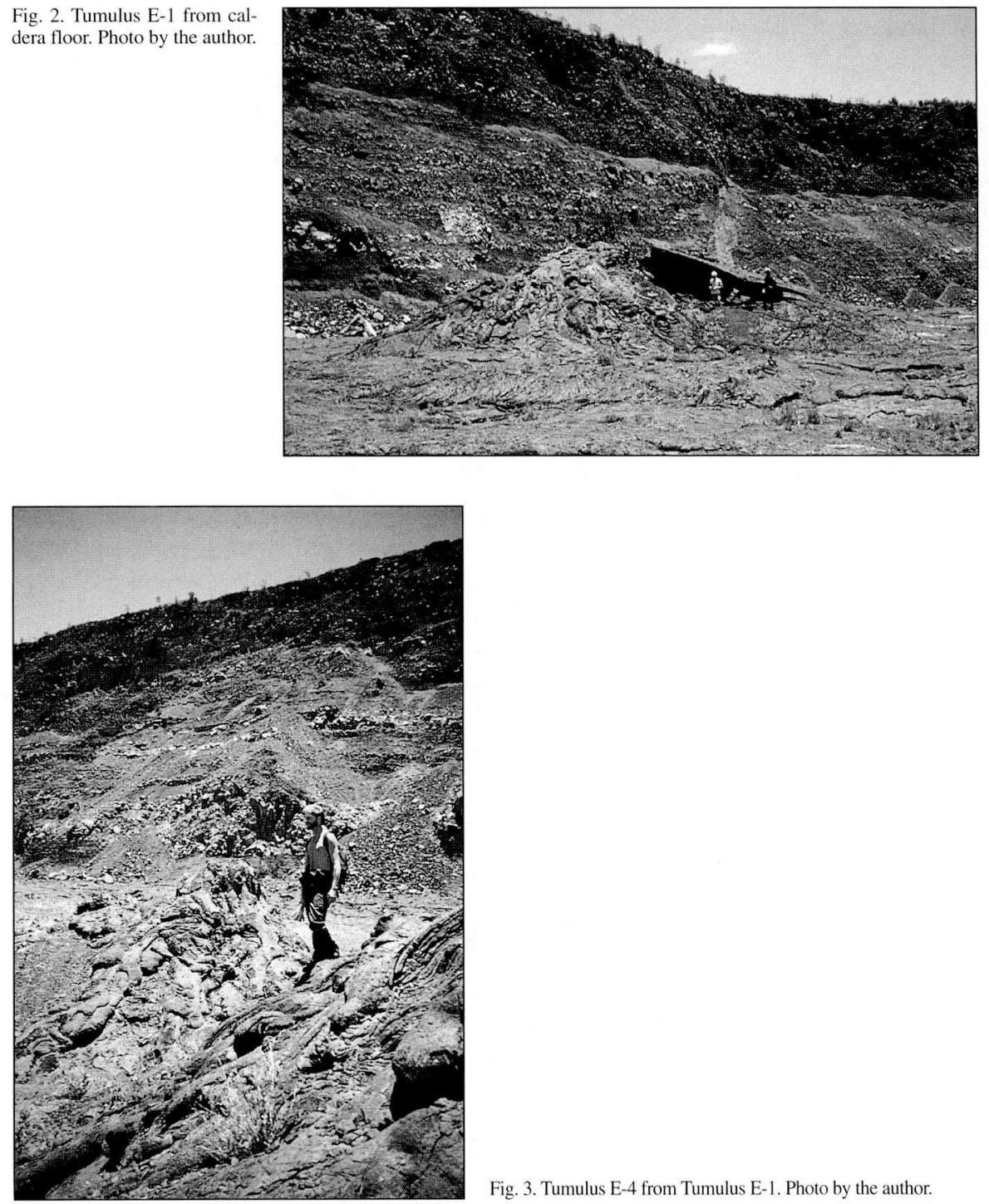

Fig. 3. Tumulus E-4 from Tumulus E-1. Photo by the author.

\section{TYPES OF HOLLOW TUMULI IN KILAUEA CALDERA}

In 1991, Walker published details of a hollow tumulus which he designated as Tumulus E-1 (Walker, 1991)(Fig. 1). It now may be considered the prototype of hollow tumuli. He described it as $24 \mathrm{~m}$ wide by $5.3 \mathrm{~m}$ high, with a cavern $43 \mathrm{~m}$ long, up to $28 \mathrm{~m}$ wide, and as much as $4.5 \mathrm{~m}$ high. He found that it had been pushed up to $5 \mathrm{~m}$ above its surroundings (Fig. 2) and that the cave extends a short distance beneath adjacent surfaces. This tumulus has a typical summit cleft, with lava outflow tongues and squeezeups. Its 


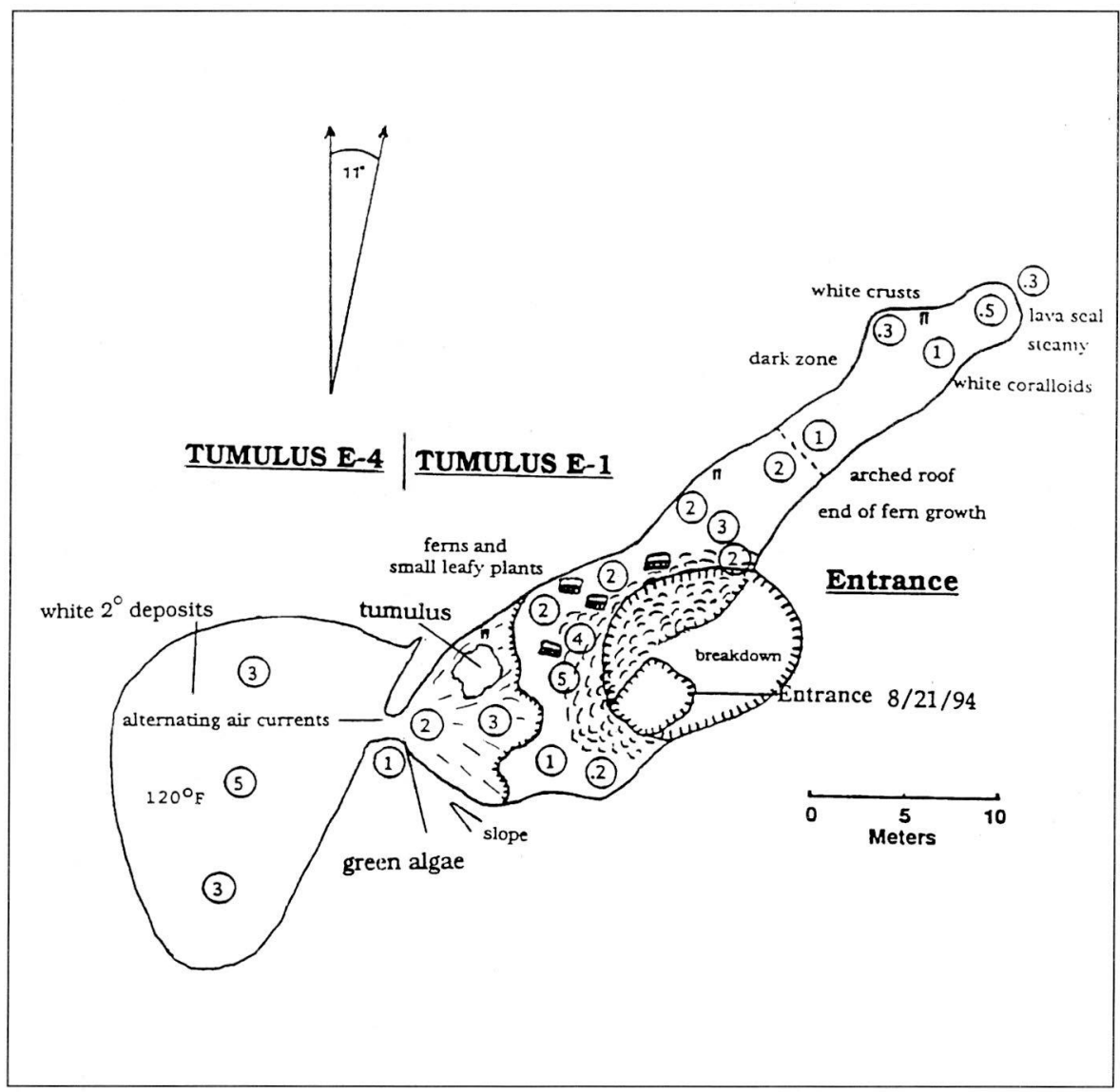

Fig. 4. Map of Tumulus E-1 Cave, Kilauea Crater, Hawaii Volcanoes National Park. Sisteco Compass/cloth tape survey, 21 August 1994 with field revision 1996, Hawaii Speleological Survey.

walls consist of tilted crusted plates lo-cally overrun by pahoehøe lava which welled up and out of the cleft. Innumerable tumuli of this type exist in the caldera, but to date, this is one of only two found to be hollow in the extensive 1919 Postal Rift lava flow. A smaller example with a simpler structure ("Standing Room Cave") is located about $0.8 \mathrm{~km}$ farther northeast in this flow. Another small example is known in a 1885 flow, and still another exists outside the caldera, $2 \mathrm{~km}$ to the northeast (Halliday, 1991, 1994).

Walker enumerated several other tumuli and some lava rises near Tumulus E-1. One of these (Tumulus E-4) is about $20 \mathrm{~m}$ southwest of Tumulus E-1. It is smaller and much more conical than Tumulus E-1 and its summit crack is not conspicuous (Fig. 3). Its general appearance is that of a wide-based driblet spire. Tumuli of this type are less common in Kilauea Caldera than the E- 1 type and Walker apparently was unaware that any are hollow. Despite their proximity, there is no surface evidence of any connection or relationship between Tumuli E-1 and E-4. Only through subsurface exploration in a hyperthermal environment was it determined that Tumulus E-4 also is hollow, and that its chamber is connected to that of Tumulus E-1, forming a single cave (Fig. 4). 


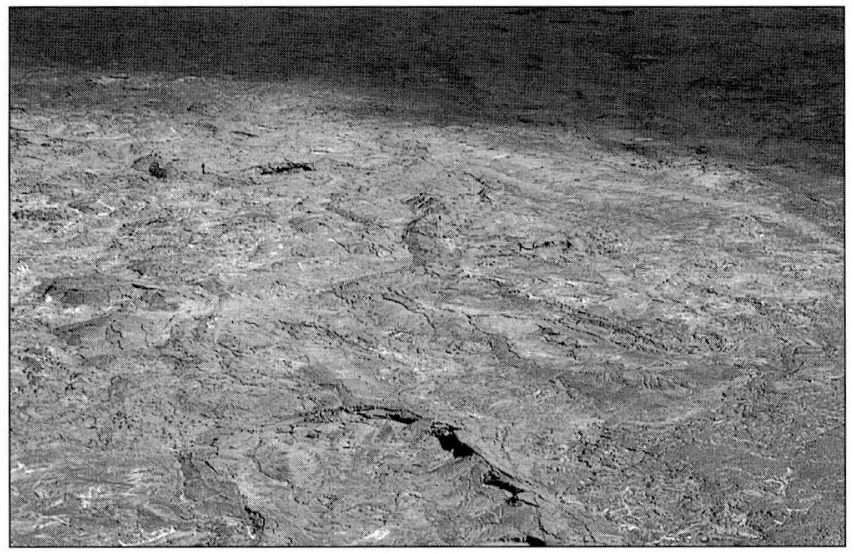

Fig. 5. View from caldera rim showing Almost Too Hot Cave tumulus and its lava rise. Sleeping Ohia and Sleeping's Sister caves' tumuli also are visible. Photo by the author.

Fig. 6. Downslope end of Almost Too Hot Cave tumulus, showing extruded lava. Photo by the author.

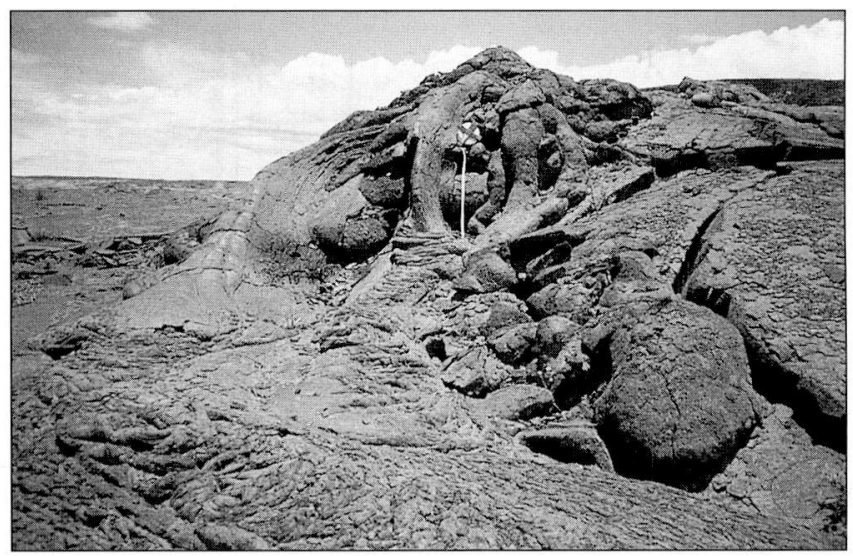

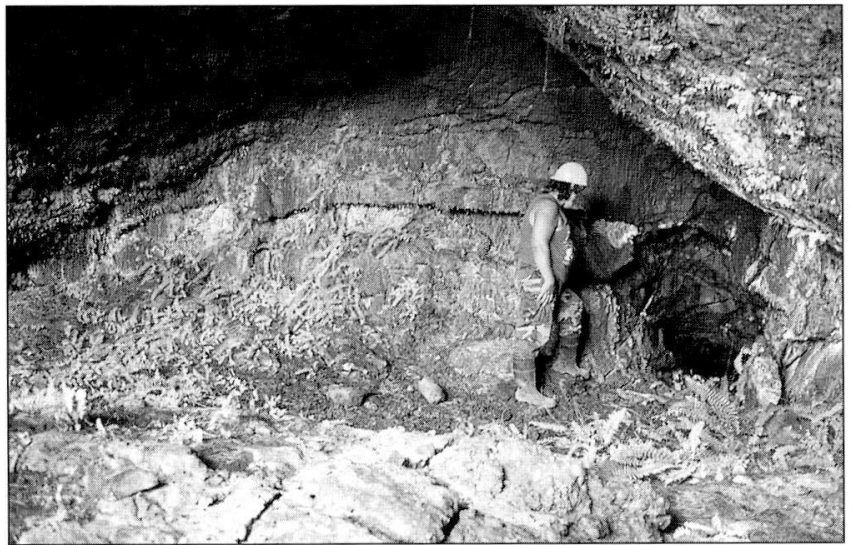

Fig. 7. Orifice between E-1 and E-4 chambers, showing scoured walls at lower end of E-1 chamber. Photo by the author. 
Two examples of a radically different type of hollow tumulus now are known about $0.5 \mathrm{~km}$ east of Tumulus E-1. These are lengthy sinuous tubular structures partially raised above the caldera floor. Axial clefts confirm them as tumuli. The tubular caves within them lack the rheogenic features of classical lava tube conduits (e.g., flow lines, downcut trenches, etc.) From the rim of the caldera, the tumulus containing Almost Too Hot Cave is easily seen to have been a pressurized drain tube for an unnamed quadrilateral lava rise with a small central depression (Fig. 5). The upper end of this cave is within one boundary ridge of the lava rise, and the tumulus itself is a lateral extension from the boundary ridge. It rises two to three meters above the surrounding lava. Its lower end is quite abrupt, with festoons of pahoehoe outflows (Fig. 6).

The other sinuous tumulus (which contains Sleeping's Sister Cave) has the appearance of having "appeared out of nowhere". Its lower end is much like that of the Almost Too Hot Cave tumulus, but its upper end consists only of small lava folds not much larger than ordinary pahoehoe ropes. Downslope, its height and width increase rapidly as it seemingly curls partway around the Sleeping Ohia complex described below. Its long downslope section closely resembles that of the Almost Too Hot Cave tumulus, and it, too, has an axial cleft. While it also clearly was the result of injection of very fluid lava beneath a plastic crust, the source of the injected lava is not apparent and presumably was well below the surface of the flow. Presumably solid tumuli of this type have been reported in Kalapana flows on the seaward flank of this volcano (Kauahikaua et al, 1990) and seemingly innumerable ridges of similar appearance are present on the caldera floor. At this time, no others are known to be hollow. Too Hot Cave may be within another example, but has not been explored due to a minimum entrance temperature of $62.5^{\circ} \mathrm{C}$.

\section{FEATURES OF THE CAVES}

The most important feature of the Tumulus E-1 chamber is the orifice Walker (1991) termed a "drain tube" (Fig. 1). It is 2 to $3 \mathrm{~m}$ long and ca. $1 \frac{1}{2} \mathrm{~m}$ in diameter, opening widely at both ends. It slopes downward from the Tumulus E-1 chamber and opens into the similar chamber beneath and within Tumulus E-4. Air temperature within the latter is relatively high under optimum conditions: up to $56^{\circ} \mathrm{C}$. Dense steam hinders observations and photographic documentation but the presence of fumarolic cracks and white mineral encrustations are seen easily. Its walls were not closely inspected but appeared to be relatively featureless. At times of less than optimum conditions, a dense plume of steam emerges from this inner chamber and rises 10 or more meters above the entrance of Tumulus E-1. The surfaces of the connecting orifice are dark and polished in appearance (Fig. 7). It appears to be a meltdown opening through the walls of adjacent sheet flow lobe chambers inflated above the surface of the surrounding lava. Commonly the air temperature is about $38^{\circ} \mathrm{C}$ at its ceiling, with wisps of steam drifting in and out. In the E-1 chamber, most of the walls have a thin accretionary lining. Along the hanging wall opposite the entrance are numerous vermiform lava stalactites. Its lower end has been scoured of the accretionary lining, revealing dense bedded lava in the wall (Fig. 7). In this area, the cave floor slopes to the orifice, with sagged fragments of lava crust "welded" to it. A well-defined ledge about $1 / 2 \mathrm{~m}$ high is present where a considerable body of still-fluid lava pulled away from more solidified lava which forms a level floor elsewhere in this chamber. Fumarolic cracks with white mineral deposits are less prominent than in the E-4 chamber, but occur especially in its low northern extension. 


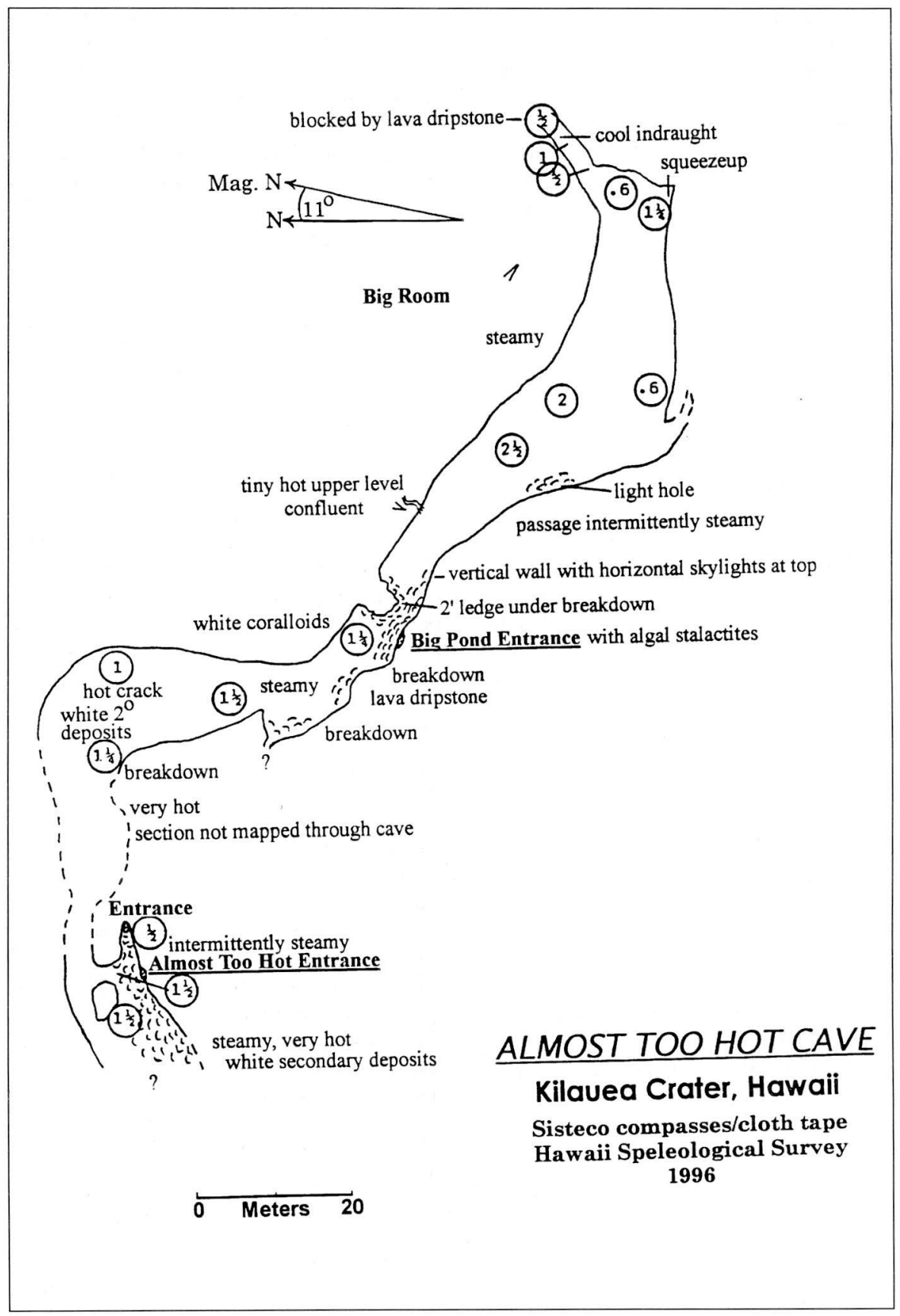

Fig. 8. Map of Almost Too Hot Cave, Kilauea Crater, Hawaii - Sisteco Compass/cloth tape, Hawaii. 
Within the Almost Too Hot Cave tumulus (Fig. 8), the air temperature upslope from the main entrance usually is greater than $56^{\circ} \mathrm{C}$. During one visit, the maximum in this main entrance chamber was only $47.8^{\circ} \mathrm{C}$ and a crawlway extending $23.7 \mathrm{~m}$ to a smaller entrance was observed. It is not shown on the map because a localized area of air temperature of $51^{\circ} \mathrm{C}$ halted exploration. Mapped length of the remainder of the cave is about $150 \mathrm{~m}$. In the Big Room near its east (lower) end, its width is 20 meters. The remainder is narrower and lower. The Big Room is walking passage; upslope from it the ceiling height is 1 to $1 \frac{1}{2}$ meters. In the Big Room the passage cross section is a flattened cylinder; upslope it is narrower. An unusual little infeeder opens on a ledge on the north wall of the Big Room; its air temperature is greater than $56^{\circ} \mathrm{C}$. The interior of this cave lacks flow lines and other common rheogenic features of lava tube caves. Patches of small vermiform lava stalactites and other lava dripstone are present. Much of the ceiling is vesicular. Especially when hot and steamy, transient white fumarolic mineral deposits are extensive in the upslope end of the cave, and elsewhere adjacent to hot cracks.

The rounded, lava-festooned downslope end of the tumulus (Fig. 6) corresponds with the downslope end of the Big Room. As shown on Fig. 10 a low terminal crawlway blocked by lava dripstone continues an unknown distance in the general direction of Sleeping's Sister Cave. On the surface at the approximate location of this terminal crawlway, a narrow width of pahoehoe has a pattern of small, closely spaced ripples extending in the same general direction.

Just upslope from the Big Room, the cave's south wall is vertical rather than curved as elsewhere in the cave. Nearby is a small cross-corridor ledge almost hidden by local breakdown. These features suggest block movement during cooling.

While the Big Room often can be visited in comfort, on other occasions dense plumes of hot steam arise from one or both principal entrances of the cave and it is much too hot to enter. The direction of wind in the caldera clearly controls ambient air temperature and steam output.

In Sleeping's Sister Cave, the maximum air temperature usually is $38^{\circ} \mathrm{C}$ or less, and the entire cave usually can he examined. On occasion, a reciprocal relationship has been observed between steam concentrations in these caves.

In general, Sleeping's Sister Cave is a smaller version of Almost Too Hot Cave. Its length is about 53 meters and its maximum width, $12 \mathrm{~m}$ (Fig. 9). Only in parts of its Big Room, downslope from its single entrance, is it possible to stand erect comfortably (Fig. 10). Unlike Almost Too Hot Cave, the axial cleft of its tumulus penetrates the ceiling of its principal section. This is the result of breakdown after cooling and the ceilings of both caves lack manifestations of the lava outflows from their axial clefts. Less lava dripstone is present than in Almost Too Hot Cave, and its walls otherwise are similarly featureless. Fumarolic cracks with white aerosolic minerals are present locally. The cave's tapering upper end permits crawling almost to the point of disappearance of the tumulus on the surface. When the cave was mapped, a cool inward breeze was present in this area.

\section{RELATED CAVES}

Hawaii Speleological Survey teams have found other caves within and beneath other mounds and ridges of the 1919 Postal Rift lava flow. To date, however, the surface features of these structures are much less clearcut than the examples cited above, and their caves are much less closely associated with surface features. Sleeping Ohia Cave 


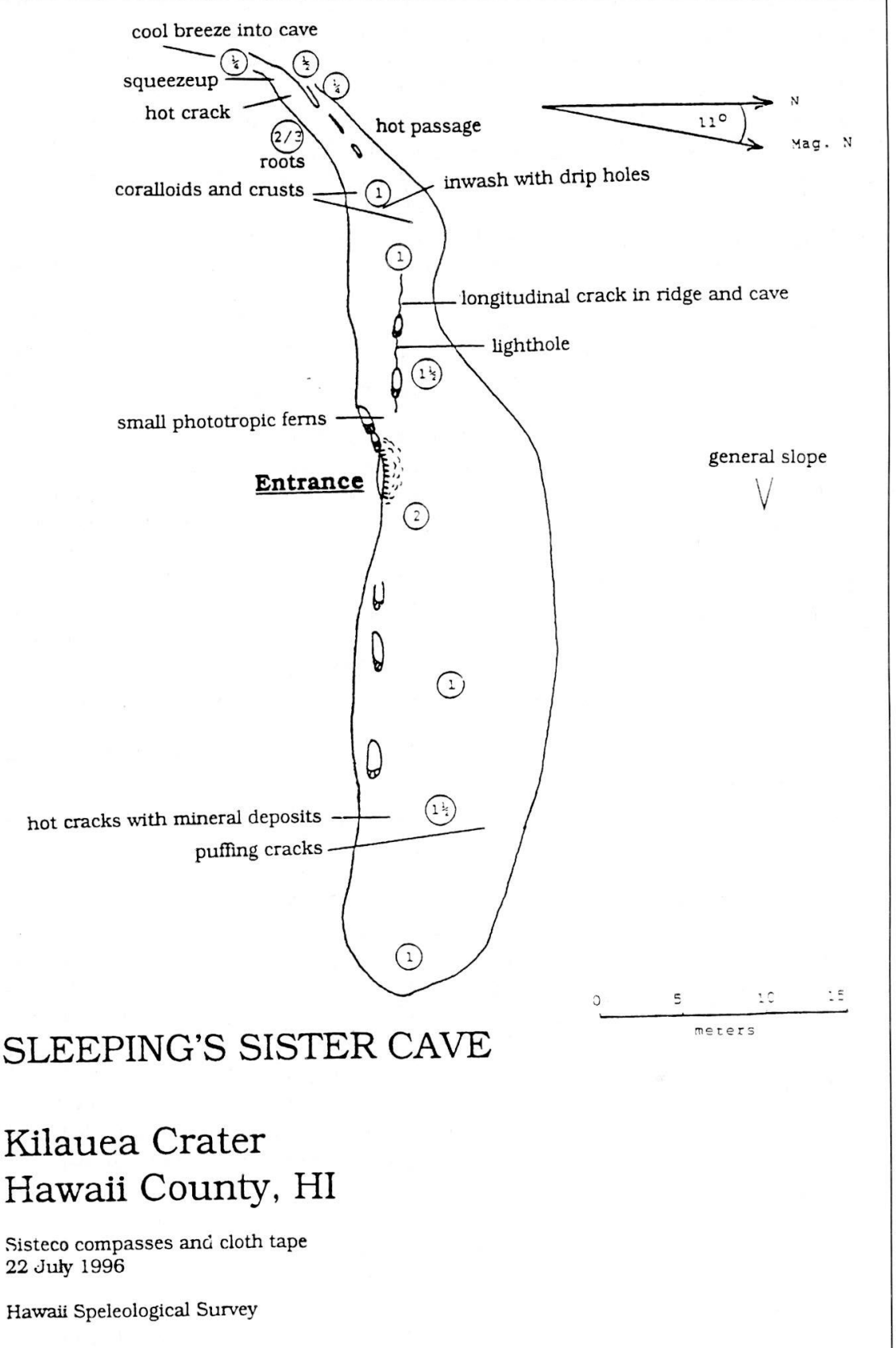

Fig. 9. Map of Sleeping's Sister Cave, Kilauea Crater, Hawaii - Sisteco Compasses and cloth tape, 22 July 1996, Hawaii. 


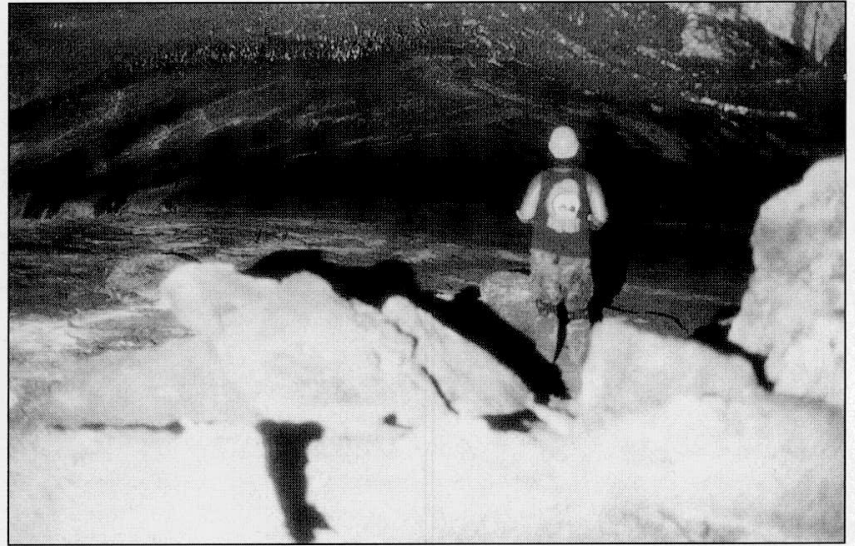

Fig. 10. Big Room of Sleeping's Sister Cave. Photo by the author.

is an example (Fig. 11). It is adjacent to Sleeping's Sister and Almost Too Hot Caves. Its entrance and part of its main room are within a small tumulus with one side collapsed, dividing its main room (Fig. 11). Much of the cave, however, is beyond the limits of the tumulus, and beneath ill-defined piles of breakout flows piled up irregularly. Within the tumulus section, part of the floor slumped into a drain tube extending downslope from the tumulus, without surface manifestation. Although the entrance of this cave is only $20 \mathrm{~m}$ from that of Sleeping's Sister Cave, and parts of the caves are much closer together, they are independent entities.

Some other caves in small lava mounds of this flow are merely drained lava breakouts with a simple remnant cavity. The origin of others is not well understood and requires additional study.

\section{CONCLUSIONS}

The additional findings reported here support Walker's assertion that hollow tumuli provide valuable insights into tumulus-forming mechanisms (Walker, 1991). They also support conclusions of Hon et al (1994) about the process of emplacement of paboehoe sheet flows, especially relating to drainage of some interconnected flow lobes. The long, sinuous type of hollow tumulus is believed to be a previously undescribed form. No conclusions are yet possible about any relationships which may exist between its caves and lava tube conduits.

\section{ACKNOWLEDGMENTS}

These studies were performed under National Park Service permit, and special thanks are due to Jim Martin and Bobby Camara for facilitating them. Jim Martin brought Tumulus E-1 Cave to the attention of the Hawaii Speleological Survey. Field interpretations by D.A. Swanson and Ken Hon contributed greatly to understanding of some of these features. The field assistance of many members and cooperators of the Hawaii Speleological Survey is hereby acknowledged, especially the contributions of Olé Fulks who discovered Sleeping's Sister Cave and participated in the hyperthermal traverse between the principal entrances of Almost Too Hot Cave. My thanks to all. 


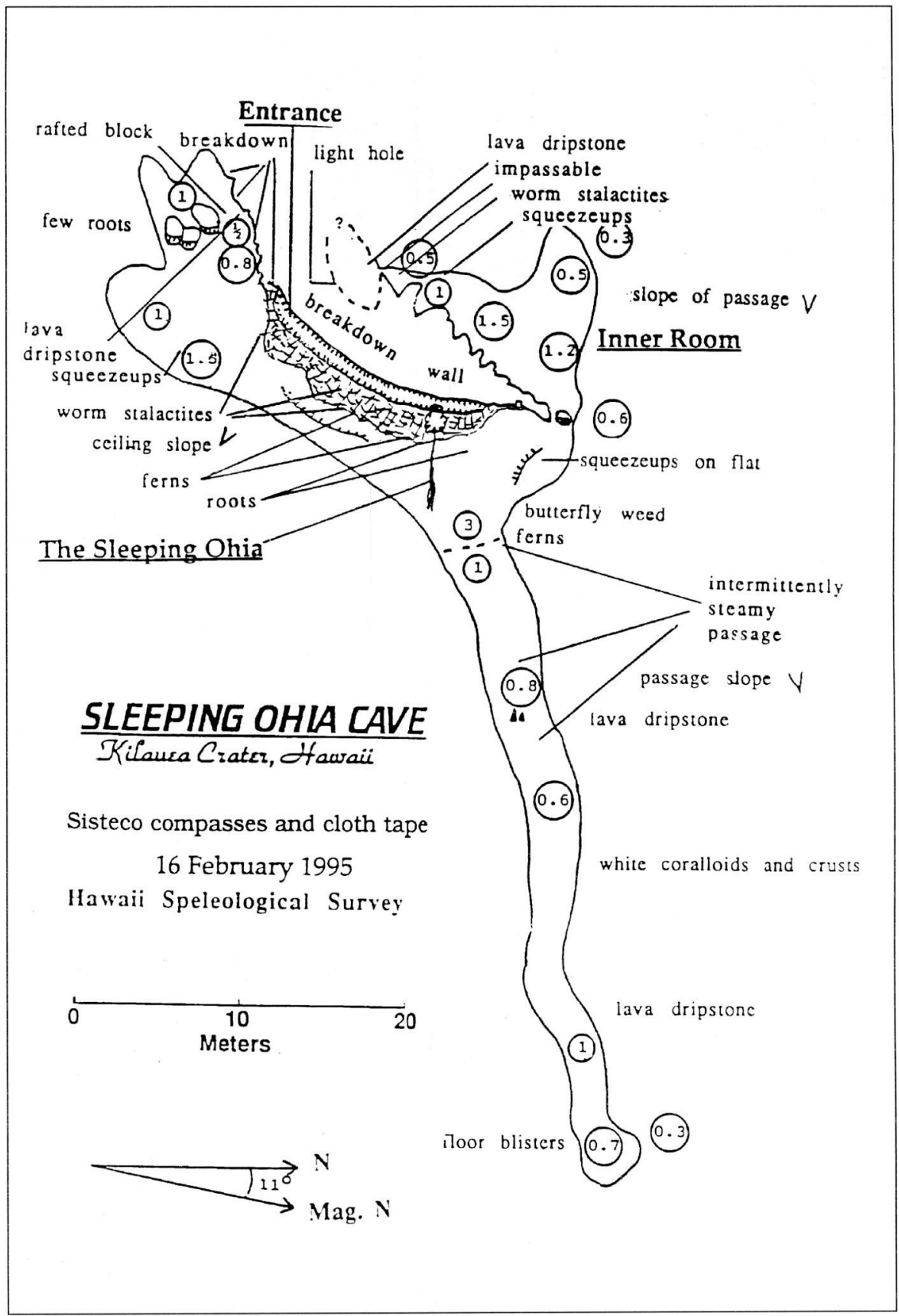

Fig. 11. Map of Sleeping Ohia Cave, Kilauea Crater, Hawaii - Sisteco Compasses and cloth tape, 16 February 1995, Hawaii. 


\section{REFERENCES}

HALLIDAY, W.R. 1991. Introduction to Hawaiian Caves: field guide for the 6th International Symposium on Vulcanospeleology, Hilo, Hawaii, August 1991. 46 p.

HALLIDAY, W.R. 1994. Caves of Kilauea Caldera: cave re-source inventory and management recommendations. Report \# 94-05, Hawaii Speleological Survey of the National Speleological Society, November 1994. 26 p. + maps.

HALLIDAY, W.R. 1997. Volunteers needed for Hawaii project. N.S.S. NEWS, vol., 53, no. 6, June, p. 168.

HON, K. ET AL. 1994. Emplacement and inflation of pahoehoe sheet flows: observations and measurements of active lava flow on Kilauea Volcano, Hawaii. Geol. Soc. Amer. Bulletin, vol. 106, p. 351, March.

KAUAHIKAUA, J. ET AL. 1990. Observations of lava tube formation in Kalapana, Hawaii. EOS, vol. 71, p. 1711.

WALKER, G.P.L. 1991. Structure, and origin by injection of lava under surface crust, of tumuli, "lava rises", "lava rise pits" and "lava inflation clefts" in Hawaii. Bull. Volcanol., vol. 52, p. 546. 